\title{
PENGARUH INSTAGRAM DAN EWOM TERHADAP MINAT DAN KEPUTUSAN PEMBELIAN KONSUMEN PRODUK SKINCARE
}

\author{
Maria Anita Carolina Kioek $^{1}$, Lena Ellitan ${ }^{2 *}$, Yuliasti Ika Handayani ${ }^{3}$ \\ 1,2,3Program Studi Manajemen Fakultas Bisnis \\ Universitas Katolik Widya Mandala Surabaya \\ Jalan Dinoyo 42-44 Surabaya \\ *Corresponding Author: lena@ukwms.ac.id
}

\begin{abstract}
This study further finds out about the influence of instagram social media and electronic word of mouth (EWOM) as promotional media on buying interest and consumer purchase decisions on Somethinc skincare products. The sampling technique used is non-probability sampling by purposive sampling. As for the background of this research is the role of the use of social media Instagram and how influential electronic word of mouth (EWOM) on buying interest and consumer purchasing decisions. The research was conducted for skincare products with the SomeThinc brand. The sampling technique used is nonprobability sampling by purposive sampling. The sample used in this study were 105 respondents. The respondents in this study were required to be at least 17 years old, have an instagram social media account and have purchased SomeThinc skincare products. The data analysis technique used is SEM-PLS analysis using the SmartPLS 3.0 program. The results of this study indicate that instagram social media has a significant effect on buying interest, instagram social media has a significant effect on consumer purchasing decisions, electronic word of mouth (EWOM) has a significant effect on buying interest, electronic word of mouth (EWOM) has an effect on consumer purchasing decisions, buying interest has a significant effect on consumer purchasing decisions, social media instagram has a significant effect on consumer purchasing decisions mediated by buying interest, electronic word of mouth (EWOM) has a significant effect on consumer purchasing decisions mediated by buying interest.
\end{abstract}

Keywords: instagram social media, electronic word of mouth, purchase intention, consumer purchase decision.

\begin{abstract}
ABSTRAK
Penelitian ini berusaha untuk menggali tentang pengaruh dari media sosial instagram dan electronic word of mouth (EWOM) sebagai media promosi terhadap minat beli serta keputusan pembelian konsumen pada produk skincare Somethinc. Adapun yang menjadi latar belakang dari penelitian ini adalah peran dari penggunaan media sosial instagram dan seberapa berpengaruh electronic word of mouth (EWOM) terhadap minat beli dan keputusan pembelian konsumen.
\end{abstract}


Penelitian dilakukan untuk produk skincare dengan merk Somethinc. Teknik pengambilan sampel yang digunakan adalah non probability sampling dengan cara purposive sampling. Sampel yang digunakan dalam penelitian ini sebanyak 105 responden. Persyaratan responden dalam penelitian ini adalah berusia minimal 17 tahun, memiliki akun media sosial instagram dan pernah melakukan pembelian produk skincare Somethinc. Teknik analisis data yang digunakan adalah analisis SEM-PLS dengan menggunakan program SmartPLS 3.0. Hasil penelitian ini menunjukkan bahwa media sosial instagram berpengaruh signifikan terhadap minat beli, media sosial instagram berpengaruh signifikan terhadap keputusan pembelian konsumen, electronic word of mouth (EWOM) berpengaruh signifikan terhadap minat beli, electronic word of mouth (EWOM) berpengaruh terhadap keputusan pembelian konsumen, minat beli berpengaruh signifikan terhadap keputusan pembelian konsumen, media sosial instagram berpengaruh signifikan terhadap keputusan pembelian konsumen yang dimediasi minat beli, electronic word of mouth (EWOM) berpengaruh signifikan terhadap keputusan pembelian konsumen yang dimediasi minat beli.

Kata kunci: sosial media instagram, electronic word of mouth, minat beli, keputusan pembelian konsumen.

\section{PENDAHULUAN}

Internet sudah menjadi kebutuhan bagi masyarakat karena banyak manfaat yang dirasakan, contohnya masyarakat dengan mudah mencari dan mendapatkan informasi yang mereka inginkan, serta saling berinteraksi satu sama lain. Penggunaan internet pada tahun 2020 di Indonesia mencapai 196,7 juta atau 73,7 persen dari populasi yang ada. Jumlah ini terus bertambah sekitar 25,5 juta pengguna pada tahun 2018 (APJII, 2018). Saat ini internet bukan hanya dimanfaatkan untuk sarana informasi, tetapi digunakan juga untuk kegiatan bisnis. Penjual dan pembeli dapat berinteraksi tidak secara langsung bertatapan muka, tetapi hanya melalui media sosial. Hal ini dapat dibuktikan dengan munculnya bisnis online. Perkembangan internet yang secara cepat juga disertai dengan kemunculan media sosial seperti facebook, twitter, youtube, instagram dan lain sebagainya. Saat ini, seperti yang dirilis oleh Asosiasi Penyelenggara Jasa Internet Indonesia (APJII) penggunaan media sosial Facebook dan instagram terbanyak dikunjungi pada tahun 2018.

Menurut data yang diterbitkan oleh Napoleon Cat, penggunaan instagram di Indonesia mencapai 269,2 juta pengguna. Napoleon Cat Indonesia menyatakan tak dipungkiri bahwa penggunaan instagram di Indonesia didominasi oleh golongan usia produktif, yakni pada rentang 18-34 tahun. Golongan tersebut mendominasi hingga 25 juta pengguna atau mendominasi 36-38 persen (usia 1824 tahun) dan 21 juta pengguna mendominasi 31-33 persen (usia 25-34 tahun). Sementara itu, tidak dipungkiri bahwa penggunaan instagram juga didominasi oleh kaum perempuan di mana mereka menggunakannya untuk membagikan 
posting-an di instagram, saling berkomentar dan berbelanja barang-barang yang mereka temui di instagram.

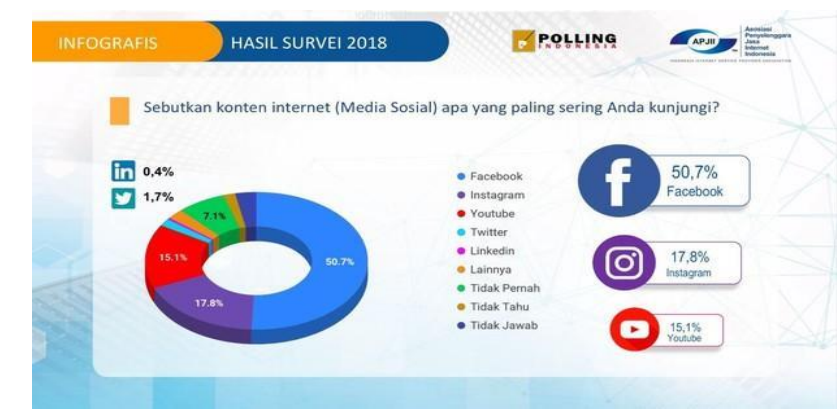

\section{Gambar 1 \\ Konten Media Sosial yang Sering dikunjungi}

Sumber: APJII (2018)

Para remaja yang suka membagikan posting-an ketika berkunjung ke suatu tempat, makan, atau menggunakan sesuatu, secara tidak langsung dapat menarik perhatian calon pelanggan untuk mencari informasi atau berkunjung. Hal ini dapat dijadikan peluang para pelaku bisnis, karena secara tidak langsung produk mereka telah dipromosikan di media sosial dan hal ini dapat meminimalisirkan biaya promosi, tetapi juga dapat meningkatkan penjualan secara lebih luas lagi.

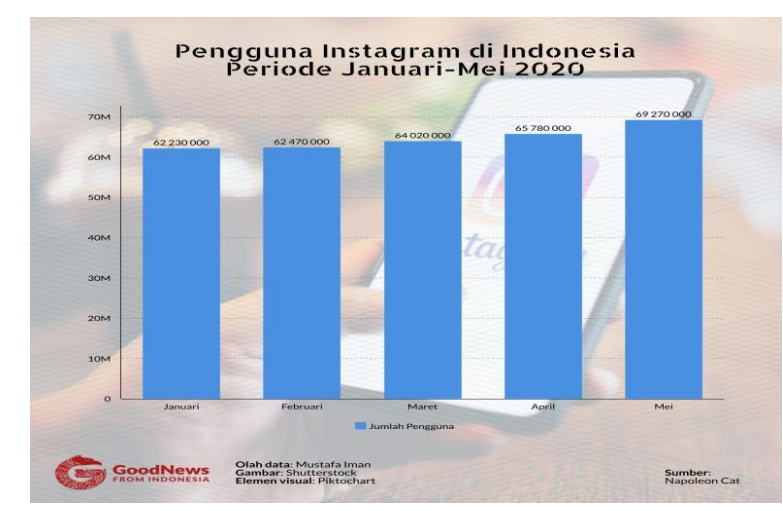

Gambar 2

Pengguna Instagram di Indonesia

Sumber: Good News from Indonesia (2020)

Sebagai media sosial yang sangat diminati oleh para pengguna, instagram juga dapat menciptakan komunikasi pemasaran secara EWOM (electronic word of mouth). EWOM adalah sebuah pernyataan baik itu positif dari orang yang telah menggunakan suatu produk atau perusahaan yang tersedia untuk banyak orang dan disebarkan melalui internet. Adanya EWOM memudahkan konsumen untuk dapat membagikan pikiran, perasaan, dan pendapat tentang suatu produk secara langsung. Fungsi dari EWOM yaitu sebagai tempat informatif untuk mendapatkan berbagai informasi (Damayanti, 2020). EWOM dapat dengan cepat, luas, dan 
mudah menyebarkan informasi. EWOM mempunyai pengaruh yang kuat terhadap perilaku konsumen daripada WOM (word of mouth). Jalilvand and Samiei (2012) menuturkan bahwa EWOM menjadi "venue" di mana hal ini penting untuk konsumen memberikan pendapat dan dianggap lebih berpengaruh dibandingkan WOM karena penyebarannya yang lebih luas daripada WOM tradisional yang bermedia offline. Hal ini disebabkan EWOM ada secara alami dari pendapat lingkungan sosial yang lebih jujur tanpa ada motif tertentu dalam menyampaikan suatu informasi kepada konsumen lainnya (Tabbane and Debabbi, 2015).

Pertumbuhan industri kosmetik perawatan kulit (skincare) di Indonesia berkembang dengan pesat dari tahun ke tahun dan kini skincare menjadi salah satu trend di Indonesia. Beragam produk skincare diciptakan dan terus berinovasi untuk menciptakan ragam yang bisa dipilih oleh kaum wanita. Dalam melakukan perawatan wajah biasanya wanita akan menggunakan produk skincare untuk menunjang mereka, rutinitas dalam melakukan tahapan-tahapan perawatan pada kulit wajah dikatakan sebagai skincare routine.

Berdasarkan data dari Kemenperin (2018) tercatat bahwa industri kosmetik nasional mencatatkan kenaikan 20\%, yakni empat kali lipat dari pertumbuhan ekonomi nasional dibandingkan periode satu tahun sebelumnya yakni tahun 2017. Pertumbuhan tersebut dikarenakan permintaan yang cukup tinggi baik dari pasar domestik, maupun ekspor. Jumlah industri kosmetik dalam negeri pada tahun 2018 sebanyak 760 perusahaan. Hal inilah yang menjadikan para pebisnis saat ini memproduksi berbagai produk skincare mulai dari yang brand lokal sampai brand luar. Salah satu brand lokal yang saat ini sedang ramai dan banyak konsumen yang menggunakannya dari sosial media instagram yaitu produk Somethinc.

Produk Somethinc memasarkan produknya melalui sosial media instagram di mana ketika satu konsumen melakukan pembelian maka terjadilah juga promosi secara EWOM yang dilakukan melalui review dan comments pada produk tersebut. Konsumen yang melakukan EWOM dapat mempengaruhi konsumen lain yang melihat, membaca, dan menonton review melalui minat beli serta keputusan pembelian konsumen pada produk skincare Somethinc. Peneliti melakukan penelitian mengenai pengaruh instagram dan EWOM terhadap minat dan keputusan pembelian konsumen produk skincare.

\section{TINJAUAN PUSTAKA \\ Media Sosial Instagram}

Media sosial yaitu perantara yang digunakan untuk pergaulan sosial secara online dengan menggunakan jejaring internet di mana para pengguna (user) media sosial dapat komunikasi, interaksi, saling mengirim pesan, saling berbagi (sharing) dan membangun networking. Sedangkan menurut Kotler dan Keller (2016: 642) "social media are a means for consumers to share text, images, audio, and video information with each other and with companies, and vice versa". Maksudnya, sosial media merupakan sarana bagi konsumen untuk berbagi teks, gambar, dan video informasi satu sama lain dengan perusahaan dan sebaliknya. Media sosial adalah teknologi berbasis internet dan sarana dialog. Perbedaan dari web tradisional adalah platformnya dalam bentuk pembuatan konten, pengunggahan konten, jaringan, dialog, berbagi media, dan bookmark 
(Tjiptono, 2017: 395). Pengguna media sosial dapat bebas meng-edit, memodifikasi baik menambahkan tulisan, gambar, video, grafis, dan berbagai konten lainnya. Media sosial yang berkembang pesat saat ini adalah instagram.

Gunelius (2010) dalam Santoso (2017) menyatakan media sosial adalah sarana pemasaran yang digunakan untuk membangun kesadaran, pengakuan, ingatan, dan tindakan akan suatu brand, product, bisnis, individu, atau kelompok, baik secara langsung maupun tidak langsung dengan menggunakan alat dari web sosial seperti blogging, microblogging, dan jejaring sosial. Instagram adalah aplikasi berbagi foto dan video yang memungkinkan pengguna mengambil foto, video, menerapkan filter digital, dan membagikannya di berbagai layanan jejaring sosial yang diterbitkan pada 6 Oktober 2010 oleh Kevin Systrom. Pada tahun 2018, instagram berkembang dengan cepat di antara pengguna seluler lainnya di kategori media sosial yang paling banyak digunakan (Katadata, 2018). Instagram dimanfaatkan untuk saluran bagi pengguna, baik konsumen dan brand, dan orang lain lebih banyak berkomunikasi dengan gambar daripada menggunakan teks. Gambar dan konten visual dapat membuat konsumen lebih mengerti informasi yang diberikan dan cara inilah yang digunakan oleh brand untuk memberikan segala informasi kepada konsumen yang pastinya setiap hari berhadapan dengan internet.

Lee et al. (2015) berpendapat instagram sudah banyak digunakan sebagai saluran media sosial. Hal ini penting untuk pemasar agar lebih mengerti motif spesifik yang dimiliki konsumen terhadap penggunaan instagram mereka dan bagaimana sebuah brand dapat memuaskan kebutuhan konsumen dan dengan demikian memperkuat hubungan antara konsumen - brand. Media sosial instagram, perlahan berubah fungsi menjadi salah satu platform pemasaran lebih populer di media sosial, baik karena banyaknya pengguna dan keunggulan visual melalui konten yang dibuat oleh penggunanya atau yang biasa dikenal dengan istilah user generated content (Duffy and Hund, 2015). Bjurling and Ekstam (2018) menyatakan konten visual efektif dalam membangun kesadaran brand dan meningkatkan percakapan, dan juga penyebaran informasi. Indikator dari media sosial menurut Ekasari (2014) adalah sebagai berikut:

1. Relationship, di mana melalui media sosial penjual membangun hubungan dengan konsumen untuk semakin dekat.

2. Komunikasi adalah percakapan antara penjual dan pembeli melalui media sosial.

3. Interaksi pasca pembelian yaitu di mana setelah konsumen melakukan pembelian maka akan terjadi interaksi pasca pembelian dapat berupa memberikan feedback berupa komentar tentang produk atau akan melakukan pembelian kembali pada sebuah produk.

4. Format informasi, memberikan informasi yang lengkap akan sebuah produk atau jasa yang dijual sehingga dapat menarik perhatian konsumen.

\section{Electronic Word of Mouth (EWOM)}

EWOM adalah sebuah bentuk kesediaan konsumen secara sukarela memberikan rekomendasi kepada orang lain untuk membeli atau menggunakan produk suatu perusahaan melalui media internet. Internet telah menimbulkan 
bentuk-bentuk baru dari komunikasi yang dapat memberdayakan perusahaan dan konsumen untuk meningkatkan komunikasi pemasaran yang lebih baik dan memungkinkan mereka untuk berbagi informasi dan pendapatan (Erkan and Evans, 2014). Kamtarin (2012) menemukan beberapa cara untuk menyebarkan informasi melalui EWOM, yaitu dengan instagram, twitter, facebook, chat room, dan masih banyak lainnya yang dapat menimbulkan konsumen untuk saling berinteraksi satu sama lain. Komunikasi media sosial ini dapat memberikan bantuan di mana para konsumen dapat saling berbagi pengalaman setelah mereka membeli dan menggunakan produk atau jasa.

Thurau et al. (2004) berpendapat EWOM merupakan pernyataan yang dibuat oleh konsumen aktual, potensial atau konsumen yang sebelumnya mengenal suatu produk atau perusahaan pada media internet.

Goyette et al. (2012) membagi EWOM dalam empat dimensi yaitu:

1. Content adalah isi informasi dari sosial media yang berkaitan dengan produk dan jasa. Indikator dari content meliputi:

1) Informasi variasi makanan dan minuman.

2) Informasi kualitas (rasa, tekstur, dan suhu makanan dan minuman).

3) Informasi dari harga yang ditawarkan.

2. Negative Valence of Opinion adalah pendapat negatif konsumen mengenai produk, jasa, dan brand.

3. Positive Valence of Opinion adalah pendapat positif konsumen mengenai produk, jasa, dan brand.

4. Intensity adalah banyaknya pendapat yang ditulis oleh konsumen dalam sebuah situs jejaring sosial. Penelitian yang dilakukan oleh Goyette et al. (2012) membagi indikator intensity sebagai berikut:

1) Frekuensi mengakses informasi dari media sosial.

2) Frekuensi interaksi dengan pengguna media sosial.

3) Banyaknya ulasan yang ditulis oleh pengguna media sosial.

Apa yang dilihat atau dialami oleh seseorang dapat menjadikannya bahan perbincangan antar individu. Konsumen tidak mudah percaya dengan iklan atau brosur yang tersebar pada media massa yang bersifat persuative. Konsumen akan lebih percaya pada informasi dari sumber terdekat mereka atau yang memiliki hubungan kerabat dan keluarga. Seiring dengan berkembangnya teknologi dan informasi internet pada saat ini, konsumen yang berperan sebagai innovator di mana konsumen menjadi sumber tentang keinginan dan preferensi. Konsumen juga dapat berperan sebagai komunikator yang meneruskan informasi, sebagai komunikator yang dapat menyampaikan ulasan atau review mereka tentang suatu produk atau jasa yang mana secara tidak langsung telah menyampaikan EWOM (Sutisna, 2001).

\section{Minat Beli Konsumen}

Minat beli konsumen merupakan keinginan seorang konsumen terhadap pemenuhan akan kebutuhan dan keinginan yang tersembunyi dalam pikiran konsumen. Minat beli konsumen selalu tersembunyi dalam setiap diri individu yang mana tidak ada seorangpun yang mengetahui apa yang diinginkan dan 
diharapkan oleh konsumen (Malik et al., 2013). Menurut Ferdinand (2006) minat beli dapat diidentifikasikan melalui beberapa indikator sebagai berikut:

1. Minat transaksional yaitu kecenderungan seseorang untuk membeli suatu produk.

2. Minat referensial yaitu kecenderungan seseorang untuk dapat mereferensikan produk kepada orang lain.

3. Minat preferensial yaitu minat yang menggambarkan perilaku seseorang yang memiliki preferensi utama pada produk tersebut. Preferensi ini hanya dapat digantikan jika terjadi sesuatu dengan produk preferensinya.

4. Minat eksploratif yaitu minat yang menggambarkan perilaku seseorang yang selalu mencari informasi mengenai produk yang diminati dan mencari informasi untuk mendukung sifat-sifat positif dari produk tersebut.

Pada dasarnya sebelum konsumen menyadari akan membeli suatu produk dari media sosial instagram yang mereka lihat terdapat beberapa tahapan. Rehman et al. (2014: 2) menjabarkan tahap-tahap dalam pengukuran menggunakan model AIDA:

1. Attention (Perhatian) adalah tahap pertama, di mana konsumen mulai sadar mengenai sebuah produk. Tahap ini yaitu pemasar memperkenalkan produk, jasa dan berbagai informasi mengenai produknya.

2. Interest (Ketertarikan) adalah tahap untuk menciptakan ketertarikan atau interest oleh pembaca, karena menciptakan ketertarikan adalah prioritas pemasar.

3. Desire (Keinginan) adalah tahap yang menunjukkan keinginan konsumen untuk membeli sebuah produk atau jasa.

4. Action (Tindakan) adalah tahap di mana konsumen sudah siap untuk melakukan transaksi untuk memenuhi keinginan akan sebuah produk.

\section{Keputusan Pembelian Konsumen}

Menurut Kotler and Keller (2016) keputusan pembelian adalah suatu tahap di mana konsumen telah memiliki pilihan dan siap untuk melakukan pembelian atau pertukaran antara uang dan janji untuk membayar dengan hak kepemilikan atau penggunaan suatu barang atau jasa. Sedangkan menurut Kotler and Armstrong (2012) tahapan dalam proses pengambilan keputusan pembelian terdiri dari lima tahap, yaitu:

1. Pengenalan Masalah, merupakan tahap pertama yaitu ketika konsumen mengenali masalah akan kebutuhan. Pada tahap ini perusahaan meneliti tentang apa yang dibutuhkan konsumen.

2. Pencarian Informasi, yaitu tahap merangsang konsumen mencari informasi lebih banyak terkait suatu produk yang mereka inginkan.

3. Evaluasi Alternatif, merupakan tahap konsumen mencari alternatif lain untuk produk yang mereka inginkan.

4. Keputusan Pembelian, yaitu ketika konsumen benar-benar membeli. Konsumen akan membeli produk yang mereka sukai, tetapi ada dua faktor yang muncul, yaitu minat untuk membeli dan keputusan pembelian.

5. Perilaku Pasca Pembelian, yaitu tahap konsumen mengambil tindakan lebih lanjut setelah pembelian berdasarkan pada rasa puas atau tidak puas. 
Dalam menentukan keputusan pembelian ada indikator yang dapat digunakan menurut Kotler and Armstrong (2012) yaitu:

1. Kemantapan pada sebuah produk

Pada saat sebelum melakukan pembelian, konsumen akan memilih salah satu dari beberapa alternatif. Pilihan berdasarkan mutu, kualitas, dan faktor lain yang memberikan kemantapan kepada konsumen untuk membeli sebuah produk yang dibutuhkan. Kualitas yang bagus dapat memberikan rasa puas kepada konsumen.

2. Kebiasaan dalam membeli produk

Kebiasaan adalah pengulangan sesuatu yang dilakukan secara terus-menerus dalam melakukan pembelian produk yang sama. Ketika konsumen telah melakukan keputusan pembelian dan mereka merasa cocok dan nyaman dengan produk yang dibeli, maka mereka akan susah untuk berpaling kepada produk lainnya.

3. Kecepatan dalam memutuskan dan membeli sebuah produk

Konsumen sering mengambil sebuah keputusan dengan menggunakan aturan (heuristik). Heuristik adalah sebuah proses yang dilakukan seseorang dalam mengambil sebuah keputusan secara cepat, dengan menggunakan sebuah pedoman umum dalam sebagian informasi saja.

4. Pemilihan alternatif dalam membeli sebuah produk

Konsumen biasanya memiliki banyak pilihan alternatif sebelum mereka membeli sebuah produk, dari sekian banyak alternatif yang ada biasanya konsumen hanya memilih satu untuk membeli sebuah produk.

5. Adanya perilaku setelah melakukan pembelian, yaitu dengan merasa puas, nyaman bahkan akan melakukan pembelian ulang pada sebuah produk.

\section{Pengembangan Hipotesis}

\section{Pengaruh Media Sosial Instagram terhadap Minat Beli Konsumen}

Kotler and Keller (2016) menemukan bahwa media sosial sebagai metode yang dilakukan oleh konsumen untuk berbagi informasi berupa teks, gambar, video, dan suara kepada orang lain. Siswanto (2013) dalam Fatimah (2020) menemukan media sosial merupakan sarana paling ampuh yang digunakan sebagai media promosi. Media sosial dapat dimanfaatkan untuk sarana pemasaran yang interaktif, pelayanan, dan menjalin hubungan dengan konsumen. Ada penelitian lain yang menunjukkan bahwa komunikasi pemasaran online dapat mempengaruhi minat beli konsumen (Balakrishnan et al., 2014 dalam Fatimah, 2020). Jurnia dan Rosyad (2015) dalam Fatimah (2020) mempelajari dampak periklanan di media sosial dan minat beli membuktikan bahwa ada hubungan yang signifikan antara beriklan di media sosial dengan minat beli konsumen. Dengan demikian hipotesis yang diajukan:

H1: Media sosial instagram berpengaruh terhadap minat beli konsumen.

\section{Pengaruh Media Sosial Instagram terhadap Keputusan Pembelian Konsumen}

Penelitian yang dilakukan oleh Nurgiyantoro (2014) dalam Fatimah (2020) menuturkan bahwa promosi yang dilakukan di media sosial berpengaruh positif 
dan signifikan terhadap keputusan pembelian konsumen yang juga dipengaruhi dengan teknik promosi lewat media sosial. Hermawan (2012:28) dalam Fatimah (2020) dengan kata red-hot, yang mendeskripsikan peluang yang besar dalam pemasaran melalui internet. Media sosial sebagai kelompok online di mana orang dapat melakukan sosialisasi dan berbagi informasi dengan tujuan membangun hubungan dan loyalitas dengan konsumen. Dengan demikian hipotesis yang diajukan:

H2: Media sosial instagram memiliki pengaruh terhadap keputusan pembelian konsumen.

\section{Pengaruh EWOM terhadap Minat Beli Konsumen}

Kotler and Keller (2007) dalam Fatimah (2020) mengatakan bahwa komunikasi dari mulut ke mulut atau EWOM adalah sebuah proses komunikasi yang memberikan rekomendasi atau saran baik secara individu atau berkelompok tentang suatu produk atau jasa yang digunakan dengan tujuan untuk memberikan informasi secara pribadi. Menurut Jalilvand and Samiei (2012) dalam Fatimah (2020) ketika konsumen membaca sebuah pengalaman yang baik atau buruk tentang suatu produk di media sosial, hal ini dapat menjadi pertimbangan saran sehingga menuju pada minat beli konsumen. Pernyataan di atas didukung oleh penelitian sebelumnya yaitu Jalilvand and Samiei (2012) di mana EWOM dapat memberikan pengaruh positif yang kuat terhadap minat beli. Thurau et al. (2004) dalam Fatimah (2020) serta Sinaga dan Sulistiono (2020) menyatakan EWOM mendorong orang mengumpulkan informasi tentang produk dan jasa yang diinginkan dari orang yang dikenal maupun dari lingkungan sekitar yang sudah menggunakan produk dan jasa tersebut dan secara kolektif dapat mendorong minat beli konsumen. Dengan demikian hipotesis yang diajukan:

H3: EWOM memiliki pengaruh terhadap minat beli konsumen.

\section{Pengaruh $E$ WOM terhadap Keputusan Pembelian Konsumen}

Ketika seorang konsumen mendapatkan kepercayaan dan keinginan mereka pada sebuah produk atau jasa dari komunikasi EWOM (Sa'ait et al., 2016), maka, pada awal konsumen melakukan keputusan pembelian konsumen sebelumnya menggali informasi tentang produk daripada hanya melihat iklan saja. Menurut Almana dan Mirza (2013) dalam Fatimah (2020) EWOM seperti komentar dan testimoni penggunaan yang menjadi penyebab utama sebelum konsumen melakukan keputusan pembelian. Kalimat ini diperkuat dengan penelitian Apriani and Pradana (2017) serta Akbar dan Sunarti (2018) yang menyatakan EWOM berpengaruh terhadap keputusan pembelian secara signifikan. Ketika saling bertukar informasi secara EWOM, konsumen akan melakukan evaluasi terhadap produk. Keputusan pembelian adalah proses ketika di mana pembeli sudah mantap untuk melakukan keputusan pembelian dan menggunakannya (Suharno, 2010 dalam Fatimah, 2020). Dengan demikian hipotesis yang diajukan:

H4: EWOM memiliki pengaruh terhadap keputusan pembelian konsumen. 
Pengaruh Instagram dan EWOM Terhadap Minat dan Keputusan Pembelian Konsumen Produk Skincare

Maria Anita Carolina Kioek, Lena Ellitan, dan Yuliasti IKa Handayani

\section{Pengaruh Minat Beli terhadap Keputusan Pembelian Konsumen}

Ada sebuah perilaku sebelum konsumen melakukan keputusan pembelian yaitu minat beli. Minat beli adalah keinginan dalam pikiran calon konsumen untuk mendapatkan produk atau layanan dalam jangka waktu yang panjang atau pendek (Sa'ait et al., 2016 dalam Fatimah, 2020). Menurut Wee et al. (2014) dalam Fatimah (2020) konsumen mau melakukan pembelian secara nyata ketika ada minat beli. Penyataan ini didukung dengan penemuan Luong et al. (2017) yang menyatakan minat beli berpengaruh positif dan signifikan terhadap keputusan pembelian. Dengan demikian hipotesis yang diajukan:

H5: Minat beli memiliki pengaruh terhadap keputusan pembelian konsumen.

\section{Pengaruh Media Sosial Instagram terhadap Keputusan Pembelian Konsumen yang dimediasi Minat Beli}

Minat beli dalam memediasi media sosial instagram dapat menimbulkan keputusan pembelian konsumen akan sebuah produk. Pada penelitian sebelumnya yang dilakukan oleh Fatimah (2020) media sosial berpengaruh signifikan terhadap keputusan pembelian di mana minat beli sebagai mediasi. Hal ini terjadi ketika semakin sering melakukan promosi melalui media sosial maka akan berdampak pula pada minat beli yang kemudian berdampak juga ke keputusan pembelian konsumen. Dengan demikian hipotesis yang diajukan:

H6: Media sosial instagram memiliki pengaruh terhadap keputusan pembelian konsumen yang dimediasi minat beli.

\section{Pengaruh Electronic Word of Mouth terhadap Keputusan Pembelian yang dimediasi Minat Beli}

Minat beli mampu memediasi EWOM terhadap keputusan pembelian. Dalam penelitian yang dilakukan Fatimah (2020) dan Luthfiyatillah et al. (2020) ketika EWOM yang dilakukan konsumen menjadi meningkat maka minat beli akan berdampak pada keputusan pembelian konsumen. Dengan demikian hipotesis yang diajukan:

H7: EWOM memiliki pengaruh terhadap keputusan pembelian konsumen yang dimediasi minat beli

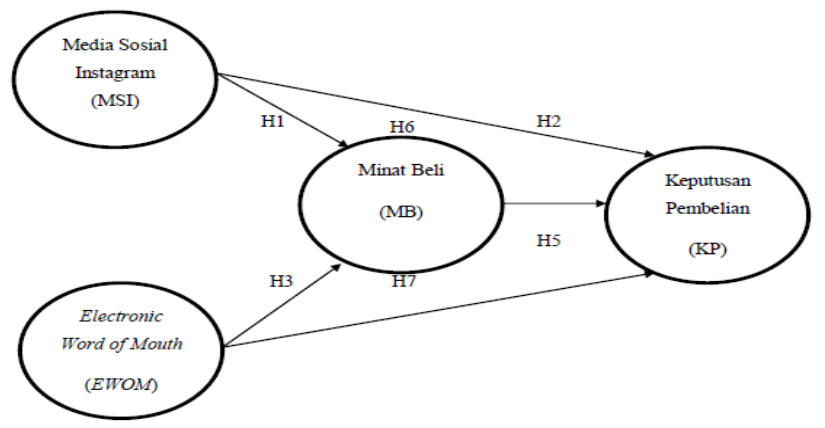

Gambar 3

Model Penelitian

Sumber: Prasetyo dan Kusumawati (2018) Diolah 


\section{METODE PENELITIAN}

Penelitian ini merupakan penelitian kuantitatif yang bertujuan menguji hipotesis dari data-data yang telah dikumpulkan sesuai dengan teori dan konsep sebelumnya. Menurut Sekaran dan Bougie (2017: 76) penelitian kuantitatif adalah metode ilmiah yang datanya berbentuk angka atau bilangan yang dapat diolah dan dianalisis dengan menggunakan perhitungan matematika atau statistika. Penelitian ini merupakan penelitian yang dimaksud untuk mengetahui ada atau tidaknya pengaruh dari media sosial instagram dan EWOM terhadap minat beli dan keputusan pembelian konsumen pada produk skincare Somethinc.

Populasi adalah wilayah generalisasi yang terdiri atas objek atau subjek yang mempunyai kualitas dan karakteristik tertentu yang ditetapkan oleh peneliti untuk dipelajari dan kemudian ditarik kesimpulannya (Sugiyono, 2018: 80). Dalam penelitian ini populasi yang digunakan adalah konsumen skincare Somethinc.

Sampel adalah sebagian dari jumlah populasi yang ada (Sugiyono, 2018: 81). Sampel dalam penelitian ini adalah konsumen skincare Somethinc. Untuk menentukan jumlah sampel digunakan ketentuan yang dikembangkan oleh Roscoe dalam Sugiyono (2018: 164) dan berpendapat bahwa ukuran sampel yang layak dalam penelitian adalah antara 30 sampai dengan 500. Oleh karena itu, dalam penelitian ini akan diambil sampel sebanyak 100 responden. Karakteristik responden yang menjadi sampel dalam penelitian ini adalah:

1. Memiliki akun media sosial Instagram

2. Berusia 17 tahun

3. Pernah melakukan pembelian produk skincare Somethinc

Variabel independen dalam penelitian ini adalah Media Sosial Instagram (MSI) dan EWOM. Variabel intervening dalam penelitian ini adalah Minat Beli (MB). Variabel dependen dalam penelitian ini adalah Keputusan Pembelian Konsumen (KP).

\section{HASIL PENELITIAN DAN PEMBAHASAN}

Pada Tabel 1 nampak hasil pengolahan data deskriptif yang dilakukan atas variabel yang digunakan.

Tabel 1

Hasil Pengolahan Data Deskriptif

\begin{tabular}{|l|l|l|l|}
\hline Variabel & Mean & $\begin{array}{l}\text { Standard } \\
\text { Deviation }\end{array}$ & Keterangan \\
\hline MSI & 3.720 & 0.567 & Setuju \\
\hline EWOM & 4.000 & 0.632 & Setuju \\
\hline KP & 4.130 & 0.391 & Setuju \\
\hline MB & 3.500 & 0.742 & Setuju \\
\hline
\end{tabular}

Media Sosial Instagram diukur dengan menggunakan 4 indikator. Total nilai rata-rata pengukuran dari variabel Media Sosial Instagram adalah sebesar 3,720 dan total nilai rata-rata standar deviasi pada variabel Media Sosial Instagram adalah sebesar 0,567. Rata-rata tertinggi terdapat pada indikator "Menurut saya 
informasi yang di dapatkan dari instagram Somethinc Official selalu lengkap dan jelas untuk setiap produknya" dengan rata-rata sebesar 4,040. Sedangkan untuk rata-rata terendah terdapat pada indikator "Instagram Somethinc Official sering mengadakan diskon dan giveaway untuk menarik perhatian saya" dengan rata-rata sebesar 3,720. Dapat disimpulkan dari total rata-rata bahwa responden yang sudah menjawab setuju pada indikator-indikator yang ada di kuesioner. Hal tersebut membuktikan bahwa rata-rata responden merasa puas terhadap produk skincare Somethinc.

EWOM diukur dengan menggunakan 4 indikator. Total nilai rata-rata pengukuran dari variabel $E W O M$ adalah sebesar 4,000 dan total nilai rata-rata standar deviasi pada variabel EWOM adalah sebesar 0,632. Rata-rata tertinggi terdapat pada indikator "Saya mengakses informasi tentang produk Somethinc melalui media sosial" dengan rata-rata sebesar 4,000 dan indikator "Saya mendapatkan informasi mengenai variasi, kualitas, dan harga produk Somethinc melalui media sosial" dengan rata-rata sebesar 4.000. Sedangkan untuk rata-rata terendah terdapat pada indikator "Saya sering membaca komentar negatif tentang produk skincare Somethinc" dengan rata-rata sebesar 2,760. Dapat disimpulkan dari total rata-rata bahwa responden sudah menjawab setuju pada indikatorindikator yang ada di kuesioner.

Keputusan Pembelian diukur dengan menggunakan 5 indikator. Total nilai rata-rata pengukuran variabel Keputusan Pembelian adalah sebesar 4,130 dan total nilai rata-rata standar deviasi pada variabel Keputusan Pembelian adalah sebesar 0,391. Rata-rata tertinggi terdapat pada indikator "Saya membeli produk Somethinc karena mempunyai kualitas yang bagus" dengan rata-rata sebesar 4,100 dan indikator "Saya merasa puas dengan hasil yang diberikan dari produk Somethinc" dengan rata-rata sebesar 4,100. Sedangkan untuk rata-rata terendah terdapat pada indikator "Saya hanya memilih produk skincare Somethinc dari sekian banyak produk skincare yang ada" dengan rata-rata sebesar 2,890. Dapat disimpulkan dari total rata-rata bahwa responden sudah menjawab setuju pada indikator-indikator yang ada di kuesioner.

Minat Beli diukur dengan menggunakan 4 indikator. Total nilai rata-rata pengukuran variabel Minat Beli adalah sebesar 3,500 dan total nilai rata-rata standar deviasi adalah sebesar 0,742. Rata-rata tertinggi terdapat pada indikator "Saya bertanya dan mencari informasi tentang produk kepada konsumen yang pernah menggunakannya sebelum membeli dan menggunakan produk skincare Somethinc" dengan rata-rata sebesar 4,170. Sedangkan untuk rata-rata terendah terdapat pada indikator "Saya memilih skincare Somethinc karena produknya lebih menarik perhatian saya daripada produk lain" dengan rata-rata sebesar 3,670. Dapat disimpulkan dari total rata-rata bahwa responden sudah menjawab setuju pada indikator-indikator yang ada di kuesioner. Pada Tabel 2 ditunjukkan hasil pengujian dari 7 hipotesis yang diajukan dalam penelitian ini dengan hasil signifikan. 
Tabel 2

Hasil Pengujian Hipotesis

\begin{tabular}{|c|l|c|c|c|c|}
\hline \multirow{2}{*}{ Hipotesis } & \multicolumn{1}{|c|}{ Pengaruh } & $\begin{array}{c}\text { Sampel } \\
\text { Original } \\
(\mathbf{O})\end{array}$ & t-Stat & $\begin{array}{c}\text { P- } \\
\text { Value }\end{array}$ & Ket. \\
\hline H1 & MSI $\rightarrow$ MB & 0,501 & 3,536 & 0,001 & Sig \\
\hline H2 & MSI $\rightarrow$ KP & 0,314 & 2,475 & 0,014 & Sig \\
\hline H3 & EWOM $\rightarrow$ MB & 0,250 & 2,433 & 0,015 & Sig \\
\hline H4 & EWOM $\rightarrow$ KP & 0,157 & 2,220 & 0,027 & Sig \\
\hline H5 & MB $\rightarrow$ KP & 0,626 & 4,459 & 0,000 & Sig \\
\hline H6 & MSI $\rightarrow$ KP melalui MB & 0,314 & 2,475 & 0,014 & Sig \\
\hline H7 & EWOM $\rightarrow$ KP melalui MB & 0,157 & 2,220 & 0,027 & Sig \\
\hline
\end{tabular}

\section{Hasil Temuan 1}

Variabel Media Sosial Instagram terhadap Minat Beli memiliki nilai t-stat sebesar 3,536 dan $p$-value sebesar 0,001. Hal ini berarti media sosial instagram memiliki pengaruh secara signifikan terhadap minat beli. Selain itu koefisiennya sebesar 0,501 menunjukkan bahwa media sosial instagram memiliki pengaruh terhadap minat beli. Dengan demikian dapat dikatakan bahwa hipotesis 1 diterima.

\section{Hasil Temuan 2}

Variabel Media Sosial Instagram terhadap Keputusan Pembelian memiliki nilai t-stat sebesar 2,475 dan p-value sebesar 0,014. Hal ini menunjukkan bahwa media sosial instagram memiliki pengaruh secara signifikan terhadap keputusan pembelian konsumen. Selain itu koefisiennya sebesar 0,314 menunjukkan bahwa media sosial instagram memiliki pengaruh terhadap keputusan pembelian konsumen. Dengan demikian dapat dikatakan bahwa hipotesis 2 diterima.

\section{Hasil Temuan 3}

Variabel WOM terhadap Minat Beli memiliki nilai t-stat sebesar 2,433 dan p-value sebesar 0,015. Hal ini menunjukkan bahwa EWOM memiliki pengaruh secara signifikan terhadap minat beli. Selain itu koefisiennya sebesar 0,250 menunjukkan bahwa EWOM memiliki pengaruh terhadap minat beli. Dengan demikian dapat dikatakan hipotesis 3 diterima.

\section{Hasil Temuan 4}

Variabel EWOM terhadap Keputusan Pembelian memiliki nilai t-stat dengan besarnya 2,220 dan nilai p-value sebesar 0,027. Hal ini menunjukkan bahwa EWOM memiliki pengaruh terhadap keputusan pembelian. Selain itu koefisiennya sebesar 0,157 menunjukkan bahwa EWOM memiliki pengaruh signifikan terhadap keputusan pembelian. Dengan demikian dapat dikatakan hipotesis 4 diterima. 
Pengaruh Instagram dan EWOM Terhadap Minat dan Keputusan Pembelian Konsumen Produk Skincare

Maria Anita Carolina Kioek, Lena Ellitan, dan Yuliasti IKa Handayani

\section{Hasil Temuan 5}

Variabel Minat Beli terhadap Keputusan Pembelian memiliki nilai t-stat sebesar 4,459 dan nilai p-value sebesar 0,000. Hal ini menunjukkan bahwa minat beli memiliki pengaruh terhadap keputusan pembelian. Selain itu koefisiennya sebesar 0,626 menunjukkan minat beli memiliki pengaruh terhadap keputusan pembelian. Dengan demikian dapat dikatakan hipotesis 5 diterima.

\section{Hasil Temuan 6}

Variabel Media Sosial Instagram terhadap Keputusan Pembelian melalui Minat Beli memiliki nilai t-stat sebesar 2,475 dan $p$-value sebesar 0,014. Hal ini menunjukkan bahwa media sosial instagram terhadap keputusan pembelian melalui minat beli berpengaruh. Selain itu koefisiennya sebesar 0,314 menunjukkan media sosial instagram melalui minat beli berpengaruh terhadap keputusan pembelian. Dengan demikian dapat dikatakan hipotesis 6 diterima.

\section{Hasil Temuan 7}

Variabel EWOM terhadap Keputusan Pembelian melalui Minat Beli memiliki nilai t-stat sebesar 2,220 dan p-value sebesar 0,027. Hal ini menunjukkan bahwa EWOM melalui minat beli berpengaruh terhadap keputusan pembelian. Selain itu koefisiennya sebesar 0,157 menunjukkan bahwa EWOM terhadap keputusan pembelian melalui minat beli berpengaruh. Dengan demikian dapat dikatakan hipotesis 7 diterima.

\section{SIMPULAN}

Penelitian ini memiliki tujuan untuk menguji Pengaruh Media Sosial Instagram dan EWOM sebagai Media Promosi terhadap Minat Beli serta Keputusan Pembelian Konsumen pada Produk Skincare Somethinc. Penelitian ini menemukan media sosial instagram berpengaruh positif dan signifikan terhadap minat beli. Hal ini membuktikan media sosial instagram memberikan pesan dan informasi yang jelas sehingga dapat menarik perhatian konsumen dengan minat beli. Di samping itu ditemukan pula bahwa media sosial instagram berpengaruh positif dan signifikan terhadap keputusan pembelian konsumen. Hal ini membuktikan bahwa ketika media sosial instagram memberikan informasi yang jelas maka dapat membuat konsumen untuk secara mantap melakukan keputusan pembelian.

Berkaitan dengan EWOM ditemukan bahwa EWOM berpengaruh positif dan signifikan terhadap minat beli. Hal ini membuktikan bahwa adanya EWOM menimbulkan rasa minat kepada konsumen. EWOM juga ditemukan berpengaruh positif dan signifikan terhadap keputusan pembelian konsumen. Hal ini membuktikan dengan adanya EWOM konsumen menjadi lebih yakin dan percaya akan produk. EWOM berpengaruh juga secara positif dan signifikan terhadap keputusan pembelian konsumen melalui minat beli. Hal ini membuktikan melalui minat beli yang ditimbulkan oleh EWOM dapat memberikan hasil akhir yaitu keputusan pembelian konsumen.

Minat beli ditemukan berpengaruh positif dan signifikan terhadap keputusan pembelian konsumen. Hal ini membuktikan setelah konsumen merasakan minat 
beli maka akan timbul juga keinginan untuk membeli produk. Media sosial instagram berpengaruh positif dan signifikan terhadap keputusan pembelian konsumen yang dimediasi minat beli. Hal ini membuktikan melalui minat beli konsumen akan berdampak pada keputusan pembelian konsumen dengan menggunakan media sosial instagram.

\section{SARAN}

Saran bagi penelitian yang akan datang diharapkan agar dapat dilakukan pengembangan penelitian yang menggunakan variabel media sosial instagram, EWOM, minat beli, dan keputusan pembelian konsumen. Diharapkan juga untuk penelitian selanjutnya dapat mengumpulkan jumlah responden yang lebih banyak lagi daripada penelitian sebelumnya, khususnya bagi responden yang pernah melakukan pembelian untuk kriteria responden yang dituju.

\section{DAFTAR PUSTAKA}

Akbar, M. J. C. dan Sunarti. 2018. Pengaruh Electronic Word of Mouth Terhadap Keputusan Pembelian (Survei pada Konsumen Restoran Sushi Tei Kelapa Gading). Jurnal Administrasi Bisnis (JAB), Vol. 60, No. 3, pp. 45-51.

APJII. 2018. Laporan Survei Internet. https://apjii.or.id/survei. Diakses pada tanggal 19 Maret 2021.

Apriani, D. and M. Pradana. 2017 The Influence of Electronic Word of Mouth (EWOM) Towards Consumers' Purchase Decision at Bakso Boedjangan Bandung. Journal of Business Management, Vol. 3, No. 1, pp. 38-44.

Bjurling, L., and V. Ekstam. 2018. Influencer Marketing's Effect on Brand Perceptions: A consumer Involvement Perspective. Master's Thesis, Lund University. Retrieved from http://lup.lub.lu.se/luur/download?func $=$ download File\&recordOId $=8949706 \&$ fileOId $=8949707$.

Damayanti, Y. 2020. Kajian Literatur Efektivitas Electronic Word of Mouth (EWOM) Dalam Meningkatkan Minat Beli Konsumen di Sosial Media. Jurnal Manajemen dan Inovasi (MANOVA), Vol. 2, No. 1, pp. 31-45, https://doi.org/ 10.15642/manova.v2i1.354.

Duffy, Brooke Erin and Emily Hund. 2015. "Having it All" on Social Media: Entrepreneurial Femininity and Self-Branding Among Fashion Bloggers. Social Media + Society, Vol. 1, No. 2, pp. 1-11.

Ekasari, Novita. 2014. Pengaruh Promosi Berbasis Sosial Media Terhadap Keputusan Pembelian Produk Jasa Pembiayaan Kendaraan Pada PT BFI Finance Jambi. Jurnal Penelitian Universitas Jambi Seri Humaniora, Vol. 16, No. 2, pp. 81-102. 
Pengaruh Instagram dan EWOM Terhadap Minat dan Keputusan Pembelian Konsumen Produk Skincare

Maria Anita Carolina Kioek, Lena Ellitan, dan Yuliasti IKa Handayani

Erkan, Ismail and Chris Evans. 2014. The Impacts of Electronic Word of Mouth in Social Media on Consumer's Purchase Intentions. International Conference on Digital Marketing. 11. http://v-scheiner.brunel.ac.uk/bitstream/2438/9706/ 1/Fulltext.pdf.

Fatimah, N. 2020. Pengaruh Sosial Media, Electronic Word of Mouth, dan Citra Merek Terhadap Keputusan Pembelian Melalui Minat Beli. Skripsi. Universitas Negeri Semarang. Semarang.

Ferdinand, Augusty. 2006. Metode Penelitian Manajemen: Pedoman Penelitian untuk Penulisan skripsi, Tesis, dan disertasi Ilmu Manajemen. Badan Penerbit Universitas Diponegoro. Semarang.

Good News from Indonesia. 2020. https://www.goodnewsfromindonesia.id/ 2020/06/14/pengguna-instagram-di-indonesia-didominasi-wanita-dan-genera si-milenial. Diakses pada tanggal 3 Maret 2021.

Goyette, I., L. Richard, J. Bergeron, and F. Marticote. 2012. E-WOM Scale: Word of Mouth Measurement Scale for E-Service Context. Canadian Journal of Administrative Sciences, Vol. 27, No. 1, pp. 5-23.

Jalilvand, M. R. and N. Samiei. 2012. The Effect of Electronic Word of Mouth on Brand Image and Purchase Intention: An Empirical Study in the Automobile Industry in Iran. Marketing Intelligence \& Planning, Vol. 30, No. 4, pp.460476.

Kamtarin, M. 2012. The Effect of Electronic Word of Mouth, Trust, and Perceived Value on Behavioral Intention from the Perspective of Consumers. International Journal of Academic Research in Economics and Management Sciences, Vol. 1, No. 4.

Katadata. 2018. Ini Media Sosial Paling Populer di Indonesia. https://databoks.katadata.co.id/datapublish/2018/02/01/media-sosial-apa-yangpaling-sering-digunakan-masyarakat-indonesia. Diakses pada tanggal 3 Maret 2021.

Kemenperin. 2018. Industri Kosmetik Nasional Tumbuh 20\%. https://kemenperin. go.id/artikel/18957/Industri-Kosmetik-Nasional-Tumbuh-20. Diakses pada tanggal 3 Maret 2021.

Kotler, Philip and Gary Armstrong. 2012. Principles of Marketing. Prentice Hall. New Jersey.

Kotler, Philip and Kevin Lane Keller. 2016. Marketing Management. 15th Edition. Pearson Education. United States.

Lee, E., J. A. Lee, J. Moon, and Y. Sung. 2015. Pictures Speak Louder Than Words: Motivations for Using Instagram. Cyberpsychology, Behavior, and Social Networking, Vol. 18, No. 9, pp. 552-556. 
Luong, Duy Binh, Thi Huong Giang Vo, and Kho Huan Le. 2017. The Impact of Electronic Word of Mouth on Brand Image and Buying Decision: An Empirical Study in Vietnam Tourism. International Journal of Research Studies in Management, Vol. 6, No. 1, pp. 53-63.

Luthfiyatillah, Afifah Nur Millatina, Sitti Hamidah Mujahidah, dan Sri Herianingrum. 2020. Efektifitas Media Instagram dan E-WOM (Electronic Word of Mouth) Terhadap Minat Beli serta Keputusan Pembelian. Jurnal Penelitian Ipteks, Vol. 5, No. 1, pp. 101-115.

Malik, M. E., M. M. Ghafoor, H. K. Iqbal, Q. Ali, H. Hunbal, M. Noman, dan B. Ahmad. 2013. Impact of Brand Image and Advertisement on Consumer Buying Behavior. World Applied Sciences Journal, Vol. 23, No. 1, pp. 117-122.

Prasetyo, C. B., dan A. Kusumawati. 2018. Pengaruh Vlog Sebagai Electronic Word of Mouth Terhadap Minat Beli dan Dampaknya Terhadap Keputusan Pembelian. Jurnal Administrasi Bisnis, Vol. 62, No. 1, pp. 118-126.

Rehman, Fazal Ur, Tariq Nawaz, Muhammad Ilyas, and Shabir Hyder. 2014. A Comparative Analysis of Mobile and Email Marketing Using AIDA Model. Journal of Basic and Applied Scientific Research, Vol. 4, No. 6, pp. 38-49.

Sa'ait, N., A. Kenyan, and M. F. Nazrin. 2016. The Effect of E-WOM on Customer Purchase Intention. International Academic Research Journal of Social Science, Vol. 2, No. 1, pp. 73-80.

Santoso, A. P. 2017. Pengaruh Konten Post Instagram Terhadap Online Engagement: Studi Kasus Pada Lima Merek Pakaian Wanita. Skripsi. Institut Teknologi Sepuluh November.

Sekaran, U. dan R. Bougie. 2017. Metode Penelitian Untuk Bisnis: Pendekatan Pengembangan Keahlian. Edisi 6. Buku 1. Cetakan Kedua. Salemba Empat. Jakarta.

Sinaga, B. A. dan S. Sulistiono. 2020. Pengaruh Electronic Word of Mouth dan Promosi Media Sosial Terhadap Minat Beli Pada Produk Fashion Eiger. Jurnal Ilmiah Manajemen Kesatuan, Vol. 8, No. 2, pp. 79-94. https://doi.org/10. 37641/jimkes.v8i2.329.

Sugiyono. 2018. Metode Penelitian Kuantitatif, Kualitatif, dan R\&D. Alfabeta. Bandung.

Sutisna. 2001. Perilaku Konsumen dan Komunikasi Pemasaran. Cetakan Pertama. PT Remaja Rosdakarya. Bandung.

Tabbane, Rym Srarfi. and Mohsen Debabi. 2015. Electronic Word of Mouth: Definition anc Concepts. In: Rathore, Sumangla and Avinash Panwar. Capturing, Analyzing, and Managing Word-of-Mouth in The Digital Marketplace. IGI Global. Hershey. pp. 1-27. https://doi.org/10.4018/978-14666-9449-1.ch001. 
Pengaruh Instagram dan EWOM Terhadap Minat dan Keputusan Pembelian Konsumen Produk Skincare Maria Anita Carolina Kioek, Lena Ellitan, dan Yuliasti Ika Handayani

Thurau, T. H., K. P. Gwinner, G. Walsh, and D. D. Gremler. 2004. Electronic Word-of-Mouth Via Consumer-Opinion Platforms: What Motivates Consumers to Articulate Themselves on the Internet? Journal of Interactive Marketing, Vol. 18, No. 1. pp. 38-52.

Tjiptono, Fandi. 2017. Pemasaran Jasa. Bayu Media. Malang. 